\title{
MANAJEMEN PEMASARAN TEH ROSELLA BERBASIS WEBSITE PADA KELOMPOK DASAWISMA DI DESA RAMPOANG KABUPATEN LUWU UTARA
}

\author{
Ahmad Ali Hakam Dani ${ }^{1}$ dan Erwina ${ }^{2}$ \\ ${ }^{1}$ Email: ahmad.ali.hd90@gmail.com \\ Program Studi Informatika Universitas Andi Djemma \\ ${ }^{2}$ Email: wina.sumardin@gmail.com \\ Program Studi Manajemen Universitas Andi Djemma
}

\begin{abstract}
Abstrak. Kelompok Dasawisma Desa Rampoang membudidayakan banyak Tanaman Herbal, salah satunya adalah Tanaman Rosella. Rosella merupakan salah satu tanaman yang cukup populer di Indonesia. Tanaman ini dikenal sebagai tanaman herbal dengan bentuk buah yang menyerupai kelopak bunga. Tanaman ini banyak dibudidayakan karena memiliki khasiat yang banyak. Berangkat dari kondisi tersebut, pengolahan Rosella menjadi teh memiliki potensi dan peluang bisnis yang cukup menjanjikan untuk kedua Kelompok Dasawisma tersebut. Namun, adanya keterbatasan dalam persolan produksi dan manajemen usaha menghambat peluang bisnis tersebut. Penggunaan media internet dalam hal ini pemanfaatan website sebagai media pemasaran menjadi salah satu solusi konkrit dalam meningkatkan potensi bisnis yang dimiliki oleh tanaman ini. Kegiatan yang dilakukan dalam menunjang manajemen pemasaran Teh Rosella yaitu Pelatihan pengelolaan manajemen usaha, Pelatihan sistem pemasaran bagi wirausaha baru, dan Pelatihan penggunaan media online sebagai media pemasaran. Hasil dari setiap pelatihan yang dilakukan menjadi masukan nyata bagi Kelompok Dasawisma Desa Rampoang Kabupaten Luwu Utara dalam memasarkan produk Teh Rosella yang mereka miliki.
\end{abstract}

Kata Kunci: Rosella, Teh Rosella dan Kelompok Dasawisma.

\section{PENDAHULUAN}

Desa Rampoang merupakan salah satu Desa yang terletak di Kecamatan Tana Lili, Kabupaten Luwu Utara, Provinsi Sulawesi Selatan. Letak lokasinya kurang lebih 80 km dari Kota Palopo, dan dapat ditempuh menggunakan mobil. Desa ini berada pada jalur jalan Patila-Munte, yang kemudian diapit oleh Desa Patila dan Desa Karondang. Desa Rampoang terdiri dari sekitar 400 Kepala Keluarga yang terbagi di Empat Dusun yakni Dusun Tondok Tangnga, Pollo Tondok, Rampoang dan Dusun Benteng. Mayoritas penduduk Desa Rampoang bermatapencarian sebagai Petani Kelapa Sawit dan Petani Padi. Di Desa ini tanaman mudah tumbuh dengan subur.

Kelompok Dasawisma Puring dan Kamboja merupakan salah satu Kelompok Dasawisma binaan Kabupaten Luwu Utara yang berlokasi di Desa Rampoang Dusun Benteng. Kelompok Dasawisma ini mulai dibentuk sejak tahun 2015. Dimana setiap kelompok terdiri dari $10 \mathrm{Ibu}$ Rumah Tangga. Kelompok Dasawisma Puring diketuai oleh Ibu Nur Ilah, sedangkan Kelompok Dasawisma Kamboja diketuai oleh Ibu Sarina. Kegiatan rutin yang dilakukan oleh kedua Kelompok Dasawisma ini yaitu bergotong royong dalam melakukan pembudidayaan tanaman yang dianggap sebagai tanaman yang memiliki khasiat sebagai obat atau lebih sering disebut dengan TOGA (Tanaman Obat Keluarga). Dengan media tanam yang cukup luas,

To Maega, 1(1), Agustus 2018| 35 
kedua kelompok ini mampu menanam tanaman obat hingga puluhan tanaman. Diawal pengolahan, Kelompok Dasawisma Puring mampu membudidayakan 42 jenis tanaman herbal sedangkan Kelompok Dasawisma Kamboja membudidayakan 38 jenis tanaman herbal. Salah satu tanaman herbal yang dibudidayakan oleh kedua Kelompok Dasawisma ini yakni Tanaman Rosella.

Rosella merupakan salah satu tanaman yang cukup populer di Indonesia. Tanaman ini dikenal sebagai tanaman herbal dengan bentuk buah yang menyerupai kelopak bunga. Tanaman ini banyak dibudidayakan karena khasiatnya yang banyak. Salah satu khasiat dari Tanaman Rosella yaitu dapat menurunkan tekanan darah. Hal ini sesuai dengan penemuan yang didapatkan oleh Rohaendi (2008) dan Munim et al (2008). Selain menurunkan tekanan darah, khasiat lain dari Tanaman Rosella dikemukakan oleh Ekanto \& Sugiarto (2011) bahwa dapat meningkatkan kemampuan fisik, dalam hal ini kemampuan fisik seseorang pada saat berenang. Tanaman Rosella di Indonesia banyak dikemas dalam bentuk Teh, yang dikenal dengan Teh Rosella.
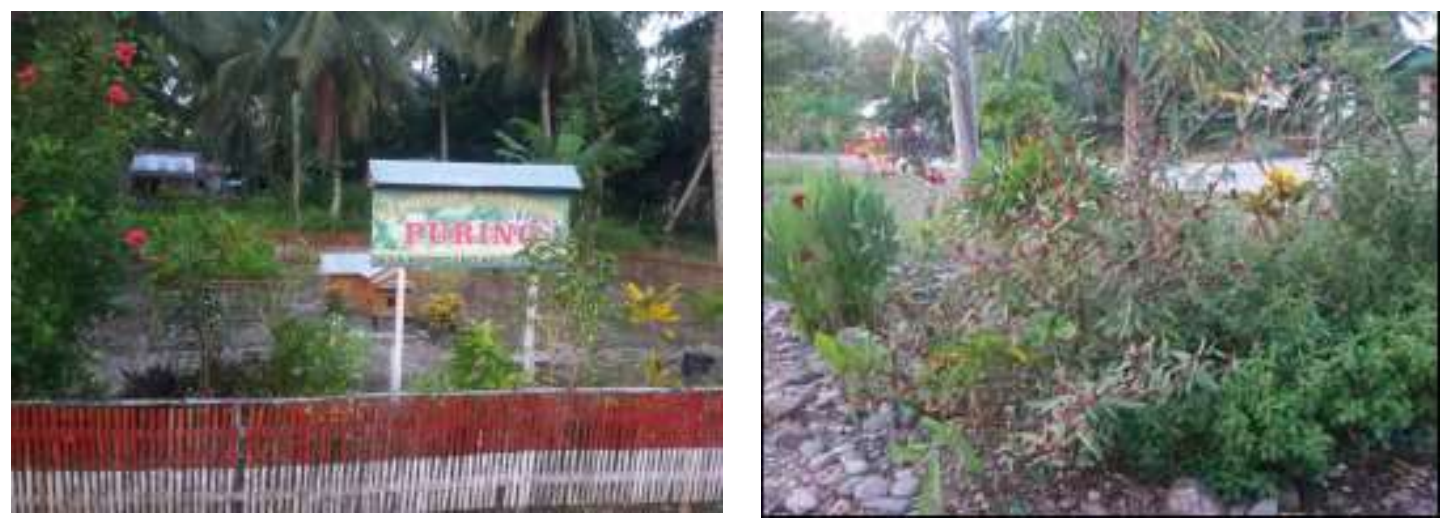

Gambar 1. Lahan Kelompok Dasawisma Desa Rampoang

Tanaman Rosella yang dihasilkan pada Kelompok Dasawisma Puring dan Kamboja tidak dimanfaatkan dengan baik. Tanaman ini hanya dibiarkan tumbuh oleh para ibu-ibu tanpa melakukan pengolahan lebih lanjut. Sementara banyak masyarakat dari Kecamatan lain yang datang dan memetik Bunga Rosella hasil budidaya dari kedua Kelompok Dasawisma ini untuk dijadikan teh, sebagai obat penurun tekanan darah. Berangkat dari kondisi tersebut, pengolahan Rosella menjadi teh memiliki potensi dan peluang bisnis yang cukup menjanjikan untuk kedua Kelompok Dasawisma tersebut.

Namun, adanya keterbatasan dalam persolan produksi dan manajemen usaha menghambat peluang bisnis tersebut. Kelompok Dasawisma Puring dan Kamboja terdiri dari kumpulan Ibu Rumah Tangga yang mayoritas pendidikannya hanya tamatan SD, SMP dan hanya beberapa orang yang tamatan SMA. Sehingga untuk pengolahan lebih lanjut akan hasil tanaman herbal khususnya Tanaman Rosella tidak termanfaatkan dengan baik. Tanaman herbal yang ditanam hanya sebatas untuk dimanfaatkan oleh anggota keluarga masing-masing Kelompok Dasawisma. Minimnya pengetahuan akan berwirausaha menjadi hambatan terbesar bagi kedua Kelompok Dasawisma ini. Kewirausahaan menurut Alma (2007) adalah kemampuan dalam hal menciptakan kegiatan usaha, sedangkan secara umum yaitu seseorang yang mempunyai 
kemampuan melihat dan menilai peluang, me-manage sumber daya yang dibutuhkan serta mengambil tindakan yang tepat guna memastikan sukses secara berkelanjutan. Padahal pengetahuan kewirausahaan berpengaruh berarti terhadap minat berwirausaha (Aprilianty, 2012).

Salah satu Permasalahan yang dihadapi oleh Kelompok Dasawisma Puring dan Kelompok Dasawisma Kamboja yakni kurangnya pemahaman akan berwirausaha dalam hal memasarkan hasil olahan Tanaman Rosella ini menjadi Teh Rosella. Padahal hasil olahan yang menjadi Teh Rosella bisa dipasarkan lebih luas menggunakan media internet dalam bentuk website sehingga bisa menambah pendapatan Kelompok Dasawisma masing-masing.

Menurut Horrigan dalam Dani (2016) bahwa terdapat aktivitas-aktivitas penting dalam internet yang dapat dimanfaatkan oleh masyarakat, yaitu 1) aktivitas internet untuk bertukar pesan, informasi, maupun dokumen; 2) aktivitas internet untuk kesenangan atau penyaluran hobi saja; 3) aktivitas internet untuk mencari informasi; dan 4) aktivtas internet untuk jual beli barang maupun jasa. Berdasarkan hal tersebut dapat diketahui bahwa dalam penggunaan internet tersebut menitikberatkan kepada tujuan dalama penggunaan internet itu sendiri. Selain itu, penggunaan internet ini juga mencerminkan kemampuan (skill) dari pengguna intenet tersebut.

Pada zaman sekarang telah banyak jenis aktivitas internetnya digunakan untuk jual beli produk maupun jasa. Peluang yang ada seperti ini bisa dimanfaatkan dengan baik oleh Kelompok Dasawisma Puring dan Kamboja ini. Ibu-ibu yang tergabung dalam kelompok tersebut bisa memasarkan hasil olahan Tanaman Rosella-nya menggunakan media website. Menurut Dwiyanto dan Rifai dalam Dani (2018) Website digunakan untuk memperoleh maupun membuat informasi dengan format hypertext. Konteks informasi yang ditampilkan bisa dalam jenis apa saja, termasuk informasi jual beli, dan setiap pengguna yang memiliki koneksi internet dalam mengakses informasi yang diinginkan. Oleh karena itu, pentingnya manajemen pemasaran The Rosella berbasis website pada Kelompok Dasawisma tersebut untuk menambah pendapatan warga di Desa Rampoang.

\section{METODE}

Rancangan kegiatan yang dilakukan dalam menunjang manajemen pemasaran Teh Rosella yaitu 1) Pelatihan pengelolaan manajemen usaha; 2) Pelatihan sistem pemasaran bagi wirausaha baru; 3) Pelatihan penggunaan media online sebagai media pemasaran. Kegiatan ini melibatkan Ibu-Ibu Rumah Tangga dari Keloompok Dasawisma Puring dan Kamboja serta mengikutsertakan anaknya yang sudah dewasa jika ada. Ditekankan kepada Ibu-Ibu maupun anak-anak yang bisa mengoperasikan komputer dengan baik. Rancangan kegiatan dititikberatkan pada pelatihan penggunaan media online sebagai media pemasaran dalam hal dibagi ke dalam beberapa tahapan, yaitu a) Pengenalan Media Jual Beli berbasis website; b) Penjelasan pentingnya penguasaan website sebagai media pemasaran; c) Pelatihan pembuatan website penjualan Teh Rosella. Dalam pelatihan pembuatan website ini, hanya menitikberatkan pada penggunaan template website yang sudah ada, seperti yang tersedia dalam Wordpress maupun Blogspot; d) Pelatihan pembelian Domain dan Hosting website penjualan The Rosella. Untuk penggunaan Domain dan Hosting terbagi menjadi dua jenis, yaitu Domain Berbayar dan Doman Gratis. Pemilihan jenis Domain tersebut disesuaikan dengan kesanggupan dari setiap anggota Kelompok Dasawisma masing-masing. 
TO MAEGA Volume 1 Nomor 1 , Agustus 2018, hlm : 35-41

\section{HASIL DAN PEMBAHASAN}

Manajemen pemasaran Teh Rosella berbasis website pada Kelompok Dasawisma di Desa Rampoang dibagi ke dalam tiga jenis kegiatan besar, yaitu:

1. Pelatihan pengelolaan manajemen usaha

Kegiatan disajikan dalam bentuk Ceramah dan Diskusi atau Tanya Jawab dengan Ibu-Ibu Anggota Kelompok Dasawisma Puring dan Kamboja. Materi disajikan dalam bentuk slide presentasi sehingga memudahkan Ibu-Ibu mengerti dengan materi yang disampaikan. Adapun materi inti yang disampaikan dalam pelatihan ini adalah dalam bentuk tips jitu dalam memulai usaha baru, yaitu a) Sikap realistis berdasarkan hasil riset terlebih dahulu; b) Kerja keras; c) Bekerja secara efisien; d) Jual manfaatnya, bukan harganya; e) Ketahui modal awal.

2. Pelatihan sistem pemasaran bagi wirausaha baru

Kegiatan disajikan dalam bentuk Ceramah dan Diskusi atau Tanya Jawab dengan Ibu-Ibu Anggota Kelompok Dasawisma Puring dan Kamboja. Materi disajikan dalam bentuk slide presentasi sehingga memudahkan Ibu-Ibu mengerti dengan materi yang disampaikan. Adapun materi inti yang disampaikan dalam pelatihan ini adalah tentang Strategi Pemasaran yang Pas untuk Bisnis Kecil, yaitu a) Membuat Logo untuk Brand atau Merek Produk; b) Mengembangkan Pemasaran menggunakan media sosial; c) Membuat Konten Blog yang menarik; d) Menggunakan Outsourcing dengan bijak; e) Menggunakan video iklan penjualan dengan efektif; f) Fokus pada pengembangan Produk sendiri, hindari terlalu banyak memikirkan pesaing. Dalam kegiatan ini dihasilkan desain kemasan Teh Rosella dari Kelompok Dasawisma Puring dan Kamboja, yang dapat dilihat sebagai berikut:
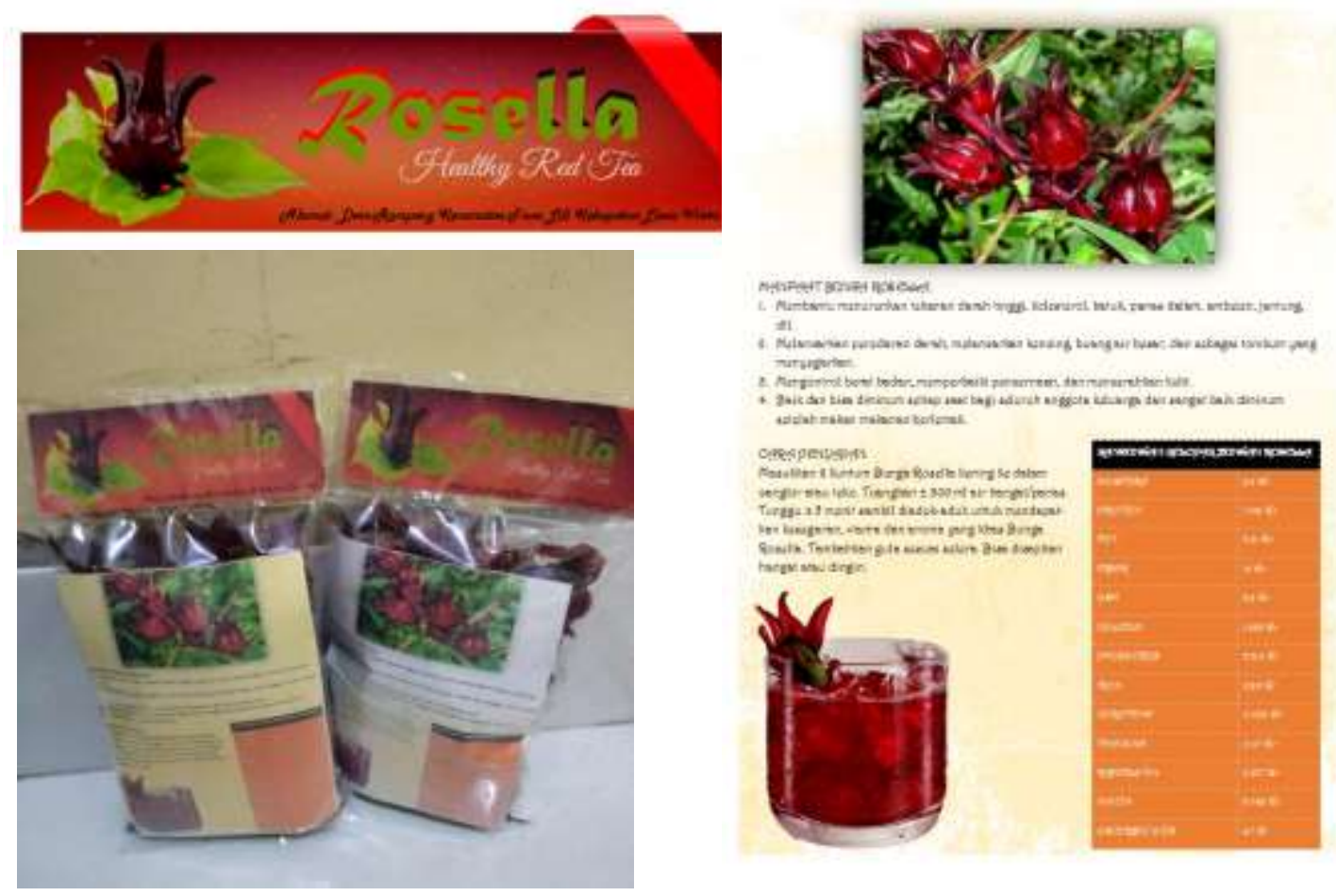

Gambar 2. Kemasan Teh Rosella Kelompok Dasawisma Desa 
Hasil olahan Tanaman Rosella dikemas sesuai dengan Gambar 2 tersebut dan siap untuk dipasarkan ke setiap daerah yang memiliki minat terhadap khasiat dari Tanaman Rosella ini.

3. Pelatihan penggunaan media online sebagai media pemasaran

Kegiatan ini dikemas dalam bentuk penyuluhan dan pelatihan dalam membuat website pemasaran Teh Rosella. Adapun tahapan kegiatan yang dilakukan adalah sebagai berikut:

a. Pengenalan Media Jual Beli berbasis website. Pada materi pengenalan ini dipaparkan website maupun aplikasi yang lagi menjadi trending topic dalam dunia jual beli belakang ini. Website maupun aplikasi tersebut bahkan sering memberikan iklan tentang layanan penggunaan aplikasinya di media Televisi. Hal ini dapat menjadi masukan bagi Ibu-Ibu Kelompok Dasawisma dalam memasarkan produk Teh Rosella kedepannya.

b. Penjelasan pentingnya penguasaan website sebagai media pemasaran. Pada materi ini ditekankan pada sistem jual beli yang lagi hangat-hangatnya dilakukan oleh setiap orang adalah menggunakan media website. Oleh karena itu, pentingnya informasi tentang Teh Rosella dari Desa Rampoang yang dikelola oleh Kelompok Dasawisma disana tampil dalam dunia online atau memiliki website sendiri yang digunakan untuk menyampaikan informasi tersebut.

c. Pelatihan pembuatan website penjualan Teh Rosella. Dalam pelatihan pembuatan website ini, hanya menitikberatkan pada penggunaan template website yang sudah ada, seperti yang tersedia dalam Wordpress maupun Blogspot. Kedua jenis template website sudah lebih dari cukup digunakan untuk memasarkan produk Teh Rosella ini. Template-template yang dimiliki Wordpress misalnya sering menjadi primadona dikalangan blogger dalam menyajikan informasinya. Selain karena template yang dimiliki Wordpress dan Blogspot sudah cukup baik digunakan dalam memasrkan produk, tetapi juga karena proses pembuatan website-nya juga lebih mudah dan cepat dibandingkan dengan pembuatan website yang dibangun dari awal menggunakan Bahasa Pemrograman PHP, HTML dan lain-lain. Peserta pelatihan ini lebih difokuskan kepada anak-anak dari Ibu-Ibu Anggota Kelompok Dasawisma tersebut. Pemilihan anak-anak ini untuk memudahkan dalam proses pelatihan pembuatan website, karena anak-anak dianggap mempunyai dasar penggunaan komputer yang lebih baik dibandingkan dengan orang tuanya. Harapannya juga adalah anak-anak inilah yang nantinya menjadi admin dari website yang sudah jadi dan dapat mengajarkan kepada orang tua mereka kedepannya. Akan tetapi, tetap diberikan kesempatan kepada Ibu-Ibu yang ingin belajar sendiri langsung dalam membuat website pemasaran tersebut.

d. Pelatihan pembelian Domain dan Hosting website penjualan The Rosella. Untuk penggunaan Domain dan Hosting terbagi menjadi dua jenis, yaitu Domain Berbayar dan Doman Gratis. Pemilihan jenis Domain tersebut disesuaikan dengan kesanggupan dari setiap anggota Kelompok Dasawisma masing-masing.

Berikut contoh website yang dihasilkan oleh Kelompok Dasawisma Desa Rampoang: 
TO MAEGA Volume 1 Nomor 1 , Agustus 2018, hlm : 35-41
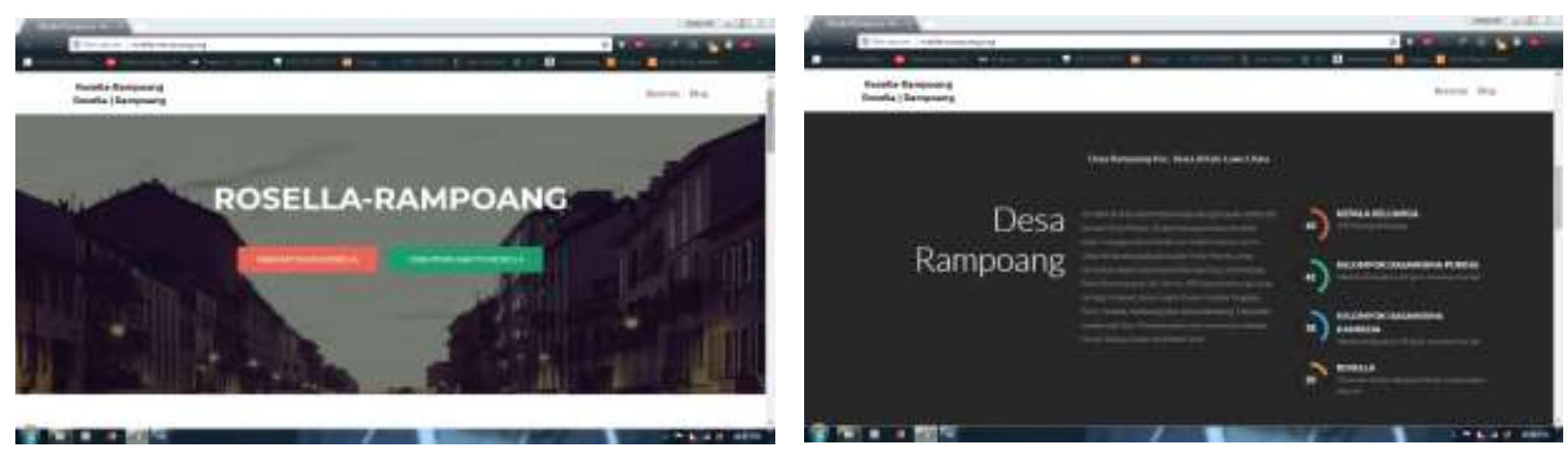

Gambar 3. Website Pemasaran Teh Rosella

Hasil website tersebut bersifat prototype, dimana dalam hal ini website tersebut masih akan terus berkembang sesuai dengan kebutuhan konten yang ingin ditampilkan. Alamat website prototype tersebut dapat diakses pada http://rosella-rampoang.org/

\section{KESIMPULAN}

Manajemen pemasaran Teh Rosella menggunakan media website sangat bermanfaat bagi masyarakat dalam hal ini Kelompok Dasawisma di Desa Rampoang. Pemasaran Teh Rosella menggunakan website memudahkan Kelompok Dasawisma ini memasarkan hasil olahan Tanaman Rosella-nya ke berbagai penjuru daerah. Pembuatan website pemasaran Teh Rosella juga tergolong mudah karena website tidak dibangun dari awal menggunakan Bahasa Pemrograman untuk Website tetapi langsung menggunakan template yang tersedia dalam Wordpress maupun Blogspot. Pada akhirnya Website dapat menunjang dalam memasarkan dan menyebarkan luaskan informasi tentang produk The Rosella yang dimiliki oleh Kelompok Dasawisma dari Desa Rampoang Kabupaten Luwu Utara.

\section{DAFTAR PUSTAKA}

Alma, B.2007. Kewirausahaan. Edisi Revisi. Alfabeta. Bandung.

Aprilianty, E., 2012. Pengetahuan Kewirausahaan, Dan Lingkungan The Effect of Entrepreneur Personality, Entrepreneurship Knowledge, and Environment on Entrepreneurial Interest. Pendidikan Vokasi, 2(3), pp.311-324.

Dani, AAH., 2016. Strategi Optimalisasi Penggunaan Internet terhadap Peningkatan Prestasi Belajar Siswa: Studi Kasus SMAN 1 Burau. Jurnal Pena Teknik, Vol 1, No. 2. (September 2016)

Dani, AAH., 2018. Sistem Informasi Penggajian Karyawan (Studi Kasus Kantor Ratona Televisi Kota Palopo). Jurnal Pena Teknik, Vol 2, No. 2 (September 2017)

Ekanto, B. \& Sugiarto, 2011. Kajian Teh Rosella (Hibiscus sabdariffa) dalam Meningkatkan Kemampuan Fisik Berenang (Penelitian Eksperimen Pada Mencit Jantan Remaja). Jurnal Media Ilmu Keolahragaan Indonesia, 1(Desember 2011).

Munim, A., Hanani, E. \& Mandasari, A., 2008. Pembuatan Teh Herbal Campuran Kelopak Bunga Rosella (Hibiscus sabdariffa) dan Herba Seledri (Apium graveolens). Majalah ilmu 
kefarmasian, 5(1), pp.47-54.

Rohaendi, H., 2008. tekanan darah pasien hipertensi primer kota tasikmalaya, pp.66-84. Available at: http://lib.ui.ac.id/file?file=digital/127173-TESIS0507HenN08pPengaruhpemberian-HA.pdf. 